Bayero Journal of Pure and Applied Sciences, 8(2): 7 - 9

Received: March, 2014

Accepted: July, 2015

ISSN $2006-6996$

\title{
GROWTH PERFORMANCE, CARCASS AND ORGAN CHARACTERISTICS OF GROWING RABBITS FED GRADED LEVELS OF MORINGA OLEIFERA LEAF MEAL IN DIETS
}

\author{
Abubakar, M., Ibrahim, U., Yusuf, A. U., Muhammad, A. S. and Adamu, N. \\ ${ }^{1}$ Animal Production Programme, Abubakar Tafawa Balewa University, Bauchi, Nigeria \\ ${ }^{2}$ Department of Animal Science, Kano University of Science and Technology, Wudil, Nigeria \\ ${ }^{3}$ Department of Animal Science, Bayero University, PMB 3011, Kano, Nigeria \\ Corresponding author: umaribrahim2005@yahoo.com, (+2348065481256)
}

\begin{abstract}
An experiment was conducted at the Department of Animal Science teaching and research farm, Bayero University Kano, to evaluate the effect of feeding graded levels of Moringa oleifera leaf meal (MOLM) in diets on growth performance, carcass and organ characteristics of weaned rabbits. Twenty eight grower rabbits of averagely $975 \mathrm{~g}$ in weight were allotted into four treatments of seven rabbits each in a completely randomize design. Four isonitrogenous diets (16\% CP) were formulated in which MOLM was included at 0, 15, 30 and 45\% for treatments 1, 2, 3 and 4 respectively. The diets were fed to the animals for eight weeks. The result showed that daily weight gain (5.95-13.39g/day) and carcass weight $(497.70-727.65 \mathrm{~g})$ increased $(P<0.05)$ with increasing levels of MOLM in diets, but dressing percentage (42.49-45.96\%) was not affected by dietary treatments. Similarly, the weight of liver (40.35-57.05g), Iungs (10.22-11.24g), heart (2.95-4.10g), kidney (8.30-10.70g), kidney fat $(11.10-12.65 \mathrm{~g})$, small intestine (81.25-99.80g), large intestine (102.45-117.95g), caecum (20.5030.50g), stomach (90.75-114.65g), spleen (1.00-1.80g) and abdominal fat (7.89-11.25g) characteristics were not different across the treatments. The results indicate that weaned rabbits can utilize Moringa oleifera leaf meal at up to 45\% level of inclusion in diets without any deleterious effects on growth performance, carcass yield and organ characteristics.
\end{abstract}

Key words: Carcass yield, growth, Moringa oleifera, organ characteristics, rabbits

\section{INTRODUCTION}

The acute shortage of animal protein in the diets of most Nigerians has been caused by the low supply and high cost of conventional meat and animal products such as beef, mutton, goat meat, poultry egg and milk. Increased rabbit production is one sure way of meeting the animal protein requirements of Nigerian populace (Iyeghe-Erakpotobor et al., 2002). Rabbits are highly prolific animals with rapid turnover rate at very low cost. The daily weight gain is high in proportion to the body weight which gives them a rapid growth rate and sexual maturity is early. These factors result in the rabbit reaching the weight of a sexually mature animal $30 \%$ faster than other animals and also make rabbit suitable as meat producing small livestock in developing countries (Ajayi et al., 2005). The rising prices of livestock feeds especially in Nigeria and the scarcity of conventional proteins and energy concentrates for the formulation of feeds have forced animal scientists to search for attractive, cheaper and readily available protein and energy sources. One of such plants is Moringa oleifera. Moringa oleifera contains adequate levels of essential amino acids (higher than the levels present in the FAO reference protein) and low level of anti- nutritive factors which indicate their high nutritional quality. Moringa oleifera leaves also have the advantage of reclamation of degraded area by increasing the organic matter content of the soil
(Makkar and Becker, 1999). This study was therefore designed to evaluate the effect of feeding graded levels of Moringa oleifera leaf meal (MOLM) in diets on growth performance, carcass and organ characteristics of weaned rabbits

\section{MATERIALS AND METHODS}

The experiment was conducted at the Animal Science Research farm, Bayero University Kano. The climate is characterized by defined wet season that normally begins in May and ends in September and dry season lasting from October to April. The annual temperature ranges between $16^{\circ} \mathrm{C}$ and $47^{\circ} \mathrm{C}$. The mean annual rainfall ranged from 600 to $1000 \mathrm{~mm}$ (KNARDA, 2001). The study lasted for eight weeks with an initial 2 weeks adjustment period. Twenty eight mongrel grower rabbits, about five weeks old and weighing averagely $975 \mathrm{~g}$ were randomly allotted to four dietary treatments of seven rabbits each in a completely randomized design. Prior to the commencement of the experiment, the housing together with the cages were thoroughly disinfected and allowed to dry. Each cage was provided with a feeder and a drinker for daily provision of feed and fresh water. Four diets (16\% crude protein) were formulated such that Moringa oleifera leaf meal was included at 0, 15, 30 and $45 \%$ for treatments 1, 2, 3 and 4 respectively. Ingredients composition of experimental diets is presented in Table 1. 
The rabbits were fed in the morning $(7.15-8.15 a m)$ daily, the quantity of feed supplied to them were weighted every morning and the left over from the previous day weighed to compute feed intake. Sixteen (16) rabbits (4 from each treatment) were used for carcass analysis. Organs such as heart, liver, kidney, lungs and spleen were weighed. The gut characteristics (small intestine, large intestine and caecum) were also weighed. Data collected were subjected to analysis of variance technique (ANOVA) as described by Steel and Torrie (1984), where significant differences existed between treatments, least significant difference was used to separate them.

\section{RESULTS AND DISCUSSION}

Growth performance, carcass quality, organs and guts dimension of weaner rabbits fed the experimental diets is shown in Table 2. The result of the daily live weight gain, which ranged from 5.95 to $13.39 \mathrm{~g} /$ day increased with increasing levels of MOLM in diets and the values were comparable to the 3.14 to $11.42 \mathrm{~g} /$ day reported by Iyeghe-Erakpotobor et al. (2006) for grower rabbits fed grass and legume combinations with concentrates. Carcass weight also increased with increasing levels of Moringa oleifera leaf meal across the diets. The values $(497.70-727.65 \mathrm{~g})$ are comparable to the 649.00 to $794.00 \mathrm{~g}$ reported by Ngele et al. (2008) for weaner rabbits fed red sorghum based diets. The dressing percentage values were within the range of 43.84 to $48.22 \%$ reported by Oluremi et al. (2006) for growing rabbits fed Cirina forda larva meal in diets. Cirina forda larva meal was reported to contain high amount of crude protein $(61.70 \%)$, which is more than twice that of Moringa oleifera leaf meal. The results of the dressing percentage indicated that despite the significant variation in the final live body weight of the animals in the current study, meat available for consumption from all the treatment diets was comparable. These values are however low when compared to the range of $50-57 \%$ recommended for rabbits under tropical conditions (Aduku and Olukosi, 1990). Differences among reported values may be due mainly to the processing methods employed (skinning, roasting or scalding) and breeds of rabbits used. Graded levels of Moringa oleifera leaf meal in diets did not influence weight of internal and external organs measured. The weight of liver $(40.35-57.05 \mathrm{~g})$ is comparable to the $42.30-53.40 \mathrm{~g}$ reported by Odeyinka et al. (2007) for weaner rabbits fed soybean milk residue, cowpea testa and corn starch residue in diets. Higher values of liver weight could be an indication of the extent of its involvement in feeds digestion and metabolism. The weight of lungs $(10.22-11.24 \mathrm{~g})$, heart $(2.95-4.10 \mathrm{~g})$, kidney $(8.30-10.70 \mathrm{~g})$ and kidney fat $(11.10-12.65 \mathrm{~g})$ were comparable to the values reported by Odeyinka et al. (2007). Other measurements which include small and large intestine, caecum, stomach, spleen, abdominal fat, tail, and legs were not affected by the dietary treatments. This is similar to the report (Joseph et al., 1997) that no significant difference was observed in carcass valuation parameters in rabbits fed different dietary levels of sweet potatoes.

\section{CONCLUSION}

Based on the results of this study, it was concluded that weaned rabbits can utilize varying levels of Moringa oleifera leaf meal at up to $45 \%$ level in diets without any adverse effects on growth performance, carcass yield, organ and gut characteristics.

Table 1: Ingredients Composition of Experimental Diets (\%)

\begin{tabular}{|c|c|c|c|c|}
\hline \multirow[t]{2}{*}{ Ingredients } & \multicolumn{4}{|c|}{ Treatments } \\
\hline & 1 & 2 & 3 & 4 \\
\hline Maize & 48.24 & 37.54 & 26.71 & 15.91 \\
\hline Soya bean meal & 18.76 & 14.46 & 10.26 & 06.09 \\
\hline Moringa oleifera leaf meal & 0.00 & 15.00 & 30.00 & 45.00 \\
\hline Maize offal (\%) & 30.00 & 30.00 & 30.00 & 30.00 \\
\hline Bone meal: & 2.00 & 2.00 & 2.00 & 2.00 \\
\hline Common salt: & 0.50 & 0.50 & 0.50 & 0.50 \\
\hline Premix & 0.50 & 0.50 & 0.50 & 0.50 \\
\hline Total & 100.00 & 100.00 & 100.00 & 100.00 \\
\hline \multicolumn{5}{|c|}{ Calculated nutrient composition (\%) } \\
\hline Crude protein & 16.00 & 15.97 & 15.99 & 16.00 \\
\hline Crude fibre & 5.67 & 8.53 & 11.70 & 14.72 \\
\hline
\end{tabular}


Table 2: Growth Performance, Carcass Quality, Organs and Guts Dimension of Weaner Rabbits fed The Experimental Diets

\begin{tabular}{|c|c|c|c|c|c|}
\hline \multirow[t]{2}{*}{ Parameter } & \multirow[b]{2}{*}{1} & \multicolumn{3}{|c|}{ Treatments } & \multirow[t]{2}{*}{ LSD } \\
\hline & & 2 & 3 & 4 & \\
\hline Initial body weight $(\mathrm{g})$ : & 900.00 & 875.00 & 983.00 & 1062.50 & - \\
\hline Final body weight $(\mathrm{g})$ : & $1150.00^{b}$ & $1200.00^{b}$ & $1500.00^{\mathrm{a}}$ & $1625.00^{\mathrm{a}}$ & $123.50^{*}$ \\
\hline Total weight gain $(\mathrm{g})$ : & $250.00^{b}$ & $325.00^{\mathrm{b}}$ & $517.00^{a}$ & $562.50^{a}$ & $48.28 *$ \\
\hline Weight gain (g/day): & $5.95^{\mathrm{c}}$ & $7.74^{\mathrm{b}}$ & $12.31^{\mathrm{a}}$ & $13.39^{a}$ & $1.62 *$ \\
\hline Carcass weight & $497.70^{b}$ & $509.85^{b}$ & $689.35^{a}$ & $727.65^{a}$ & $164.89 *$ \\
\hline Dressing percentage (\%) & 43.28 & 42.49 & 45.96 & 44.78 & $12.47^{\text {ns }}$ \\
\hline Liver $(\mathrm{g})$ & 40.35 & 45.10 & 44.70 & 57.05 & $4.75^{\mathrm{ns}}$ \\
\hline Lungs (g) & 10.35 & 10.48 & 11.24 & 10.22 & $5.01^{\text {ns }}$ \\
\hline Heart (g) & 3.00 & 2.95 & 3.65 & 4.10 & $2.62^{\text {ns }}$ \\
\hline Kidney (g) & 8.30 & 8.50 & 10.70 & 9.90 & $5.67^{\text {ns }}$ \\
\hline Kidney fat (g) & 11.10 & 12.65 & 12.20 & 11.52 & $6.75^{\mathrm{ns}}$ \\
\hline Small intestine (g) & 87.60 & 81.25 & 99.80 & 99.70 & $20.28^{\text {ns }}$ \\
\hline Large intestine (g) & 105.55 & 102.45 & 117.95 & 112.90 & $26.39^{\text {ns }}$ \\
\hline Caecum (g) & 30.50 & 24.70 & 24.90 & 20.50 & $4.67^{\text {ns }}$ \\
\hline Stomach (g) & 90.75 & 103.35 & 114.65 & 97.20 & $12.32^{\text {ns }}$ \\
\hline Spleen $(\mathrm{g})$ & 1.10 & 1.45 & 1.00 & 1.80 & $1.34^{\text {ns }}$ \\
\hline Abdominal fat (g) & 10.85 & 8.35 & 7.89 & 11.25 & $2.34^{\mathrm{ns}}$ \\
\hline
\end{tabular}

$\overline{a, b}-$ means in the same row with different superscripts are significantly different $(*=\mathrm{P}<0.05)$; ns = Not Significant, LSD $=$ Least significant difference.

\section{REFERENCES}

Aduku, A.O. and Olukosi, J.O. (1990): Rabbit management in the tropics. G.U Publishers, Zaria Nigeria.

Ajayi, F.O., Balogun, O.O., Ovuru, S.S. and Mgbere, O.O. (2005): Reproductive performance of rabbits fed maize- milling waste based diets. African Journal of Biotechnology, 3(5):439-443.

Iyeghe- Erakpotobor, G.T., Ndoly, M., Oyedipe, E.O., Eduvie, L.O. and Ogwu, D. (2002): Effect of protein flushing on reproductive performance of multiparous does. Tropical Journal of Animal Science, 5(1):123-129.

Iyeghe- Erakpotobor G.T., Aliyu, R. and Uguru, J. (2006): Evaluation of concentrate, grass and legume combinations on performance and nutrient digestibility of grower rabbits under tropical conditions. African Journal of Biotechnology, 4 (20): 2004-2008.

Joseph, A.J., Awosanya, B. and Raji, N.O. (1997): The effect of different dietary levels of sweet potato on the performance and carcass quality of rabbits. Journal of Applied Tropical Agriculture, 2(2):120-124.

KNARDA (2001): Kano Agricultural and Rural Development Authority. Kano Meteorological station reports. Record books management unit, 11.1-3.

Makker, H. P. S. and Becker, K. (1999): Plant toxin and detoxification methods to improve feed quality of tropical seeds: A review. Asian-Australian Journal of Animal Science, 2(3): 467-480

Ngele, M. B., Abubakar, M., Kalla, D.J.U., Ngele, G.T., Egbo, M. L. and Bernard, P.D.D. (2008): The effects of red sorghum based diets on the carcass and organ characteristics of rabbits. Animal Production Research Advances, 4 (3\&4): 176- 180.

Odeyinka, S.M., Olasunde, O. M. and Oyedele, O. J. (2007): Utilization of soybean milk residue, cowpea, testa and corn starch residue by weaner rabbits. Livestock Research for Rural Development, 19 retrieved from www.cipav.org.co/Irrd/Irrd19/odey.

Oluremi, O.I.A., Bogbenda, M. and Mkah, T. P. (2006): The effect of Cirina forda larva meal in rabbit diets on performance, carcass quality and nutrient digestibility. Livestock Research for Rural Development, 18 retrieved from WwW.cipav.org.co/Irrd/Irrd18/olur.

Steel, R. G. D. and Torrie, J. H. (1980): Principles and Procedures of Statistics. $2^{\text {nd }}$ edition. McGrawHill Incorporated, Tokyo, Japan 633Pp. 